\title{
DEVELOPMENT OF NUTRITIOUS COOKIES BY INCORPORATING KODO AND LITTLE MILLET FLOUR
}

\author{
P. HIMABINDU ${ }^{1} \&$ N. DEVANNA ${ }^{2}$ \\ ${ }^{I}$ Research Scholar, Department of Food Technology, JNTUA, Anantapur, Andhra Pradesh, India \\ ${ }^{2}$ Professor, Department of chemistry, JNTUA-College of Engineering, Anantapur, Andhra Pradesh, India
}

\begin{abstract}
An experiment was under taken with an attempt to exploit the commercial use of Kudo and little millet, and to improve the nutritive value of the products developed from the kodo and little millet grains by incorporating butter and coconut powder. Kodo and little millet grains were malted by soaking in potable water for 18 hours, germination by 30 hrs followed by shade drying at room temperature

Two types of cookies were prepared in the present investigation: Attempts have been made to develop cookies by the addition of optimized proportions of malted kodo millet flour and little millet flour, refined flour, sugar, butter and coconut powder. Two varieties of cookies were prepared namely butter cookies and coconut cookies by using optimized proportions of kodo millet flour, little millet flour, refined flour and other ingredients like butter and coconut powder, sugar etc. Both two types of cookies i.e. butter cookies and coconut cookies are developed in three combinations of kodo millet flour, little millet flour and refined flour, in the ratio of 25:25:50, 30:30:40 and 35:35:30 respectively. The butter cookies and coconut cookies prepared in three combinations are evaluated by sensory panel. Results revealed that among all the formulations tried, the 35:35:30 flour combination cookies got higher sensory scores. So the samples with higher sensory scores are subjected to the further chemical analysis and shelf life studies. These samples contain higher values of protein, fiber, and minerals (i.e. Calcium, Iron and Phosphorous) than the control sample. The most acceptable samples are then packed in HDPE and subjected for storage study for a period of three months at cool and dry place at normal room temperature. Sensory scores shows decreasing trend in overall acceptability of the products with increase in storage.
\end{abstract}

KEYWORDS: Cookies, Kodo Millet Flour, Little Millet Flour, Millets \& Malting

Received: Jul 06, 2017; Accepted: Jul 31, 2017; Published: Aug 08, 2017; Paper Id.: IJASRAUG201789

\section{INTRODUCTION}

In recent years, millets are recognized as important substitutes for major cereal crops to cope up with world food shortage and to meet the demands of increasing population of both developed and developing countries (Rachie 1975).Millets are the group of highly variable small seeded grasses widely grown around the world as cereal crops or grains for fodder and human food. Millets are important crops in semiarid tropics of Asia and Africa (especially in India, Mali, Nigeria and Niger) with $97 \%$ of millet production in developing countries. The crop favored due to its productivity and short growing season under dry, high-temperature condition. The kodo millet contains high amounts of polyphenols and antioxidant compounds. They also rich in fibre and low on fat. Kodo millet inhibited glycation and cross linking of collagen, which are good for diabetics (Crawford, GaryW \& Lee, and Gyound-Ah-2003). Little millet seeds are smaller than other millets like Foxtail millet. Little millet is high in iron content and high in fiber like kodo millet and high antioxidant activity. It helps diabetes and problems 
related to stomach. Malting of grains causes a significant reduction in the anti-nutritional components thus improving the availability of nutrients of malt. Malting has also been reported to help increase the in vitro digestibility, improves the sensory quality and extends the shelf life of the product (sehgal et al., 2003).The iron content in kodo millet ranges from 25.86ppm to 39.60ppm (Chandel et al., 2014).

Malting serves the purpose of converting insoluble starch to soluble starch, reducing complex proteins, generating nutrients for yeast development, and the development of enzymes (Goldammer, 2008). Literature survey reveals that, malting has been the active and expedient way for value addition of cereals (Adeyemo, Olayode and Odutuga, 1992; Akpapunam, Igbedioh and Aremo, 1996).

\section{MATERIALS AND METHODS}

Kodo and little millet are procured from TIMBUCTU organization (Penukonda, Anantapur district) other ingredients like maida, butter; coconut powder, sugar etc are procured from local market. Kodo and little millet grains were malted by soaking in potable water for 18 hours, germination by $30 \mathrm{hrs}$ followed by shade drying at room temperature, after complete drying grains are roasted for good flavor and powdered by using grinder. Two types of cookies namely butter cookies and coconut cookies were prepared by using combinations of malted kodo and little millet flour and other ingredients. Butter cookies were prepared by using three combinations of kodo and little millet flour and refined flour i.e. 25:25:50,30:30:40 and 35:35:30 and by using other ingredients like butter(30gm),sugar(50gm),egg, baking powder, cardamom powder etc. Coconut cookies were also prepared in the same way by using the same ingredients and the extra ingredient used in coconut cookies was coconut powder (30gm).

\section{METHOD FOR PREPARATION OF COOKIES}

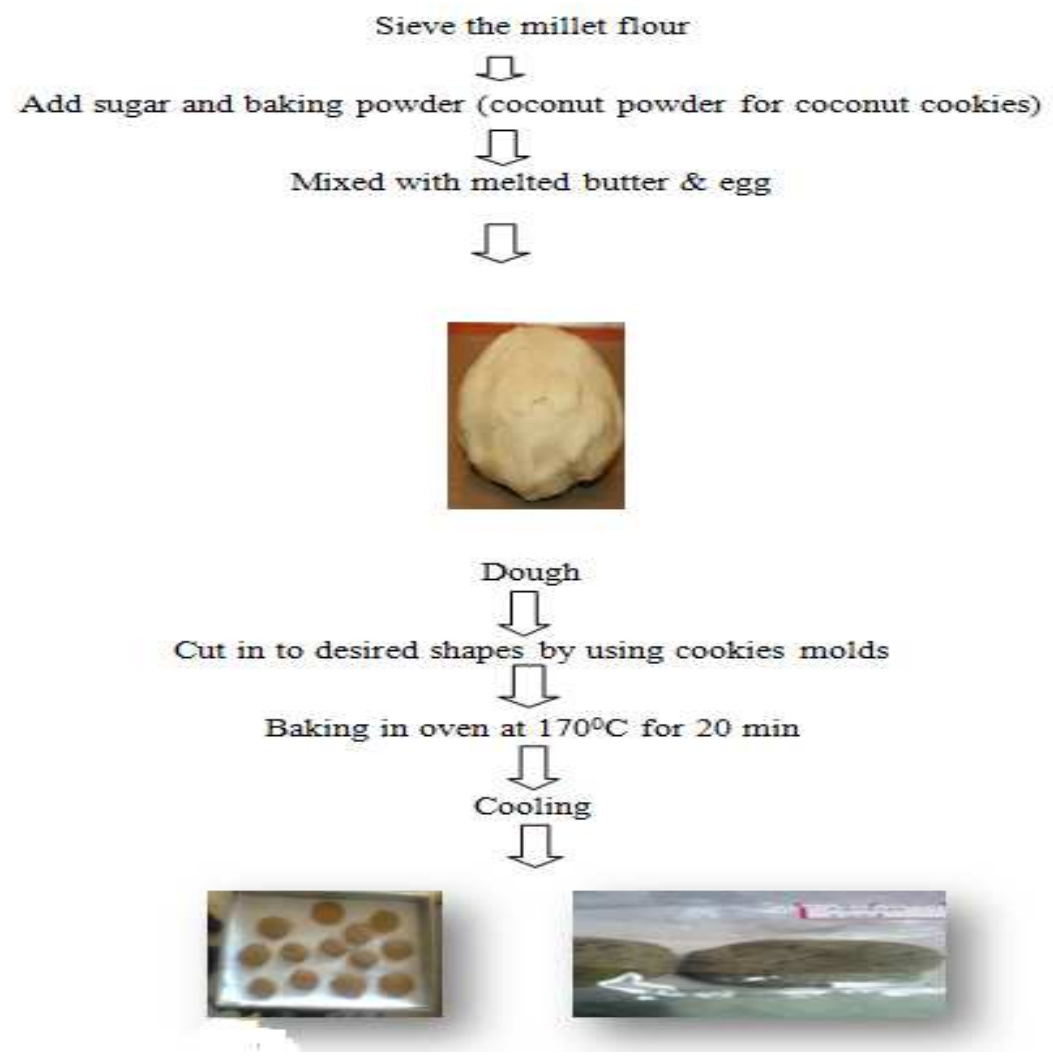

Figure 1 


\section{Testing Acceptability of the Product}

Normal butter cookies with refined flour were taken as control. The experimental products along with control were evaluated, by a selected panel of 8 judges for their sensory characteristics by using composite scoring method (Amerine, et al., 1965). A score card was prepared separately for each type of malt mix and numerical scores were assigned for each attribute. The attributes considered during the study were flavor, taste, mouth feel, color, appearance and overall acceptability. Judges were to evaluate based on scores assigned. The best sample i.e. coconut cookies with 35:35:30 (kodo millet flour: little millet flour: refined wheat flour) was identified. This sample was subjected for further nutritional analysis and storage studies.

\section{Nutrient and Physico-Chemical Analysis}

The control (RFICC) and the most acceptable (MFICC) samples were analyzed for moisture, crude fiber and fat by using the method of AOAC,1990.The protein content was estimated using Lowry's colorimetric method and calculated as $\mathrm{g} \%$ of protein(Lowry, et al.,1951). Carbohydrates are also determined by using the method of DGHS manual

\section{Storage Studies}

Packaging of most acceptable cookies was done in HDPE and laminated pouches and the samples were stored at ambient temperatures. The acceptability of the stored sample was evaluated by the same panel of judges selected earlier. A five point hedonic scale was used to rank each of the attribute of the products. Sensory evaluation was carried out periodically after 15, 30, 45 and 60 days during the 2 months storage period by the same panel of judges.

\section{RESULTS AND DISCUSSIONS}

\section{Acceptability of the Product}

The sensory evaluation of the newly developed products revealed that combination of 35:35:30 kodo, little and refined flour incorporated coconut cookies obtained least standard deviation (SD) among the normal butter cookies. So the most acceptable sample was selected for quality evaluation and storage studies.

\section{Nutrient and Physico chemical Analysis}

The result for the nutrient and physico-chemical analysis of refined flour coconut cookies (control) and most acceptable millet flour incorporated coconut cookies is present in Table1 and Figure 1.

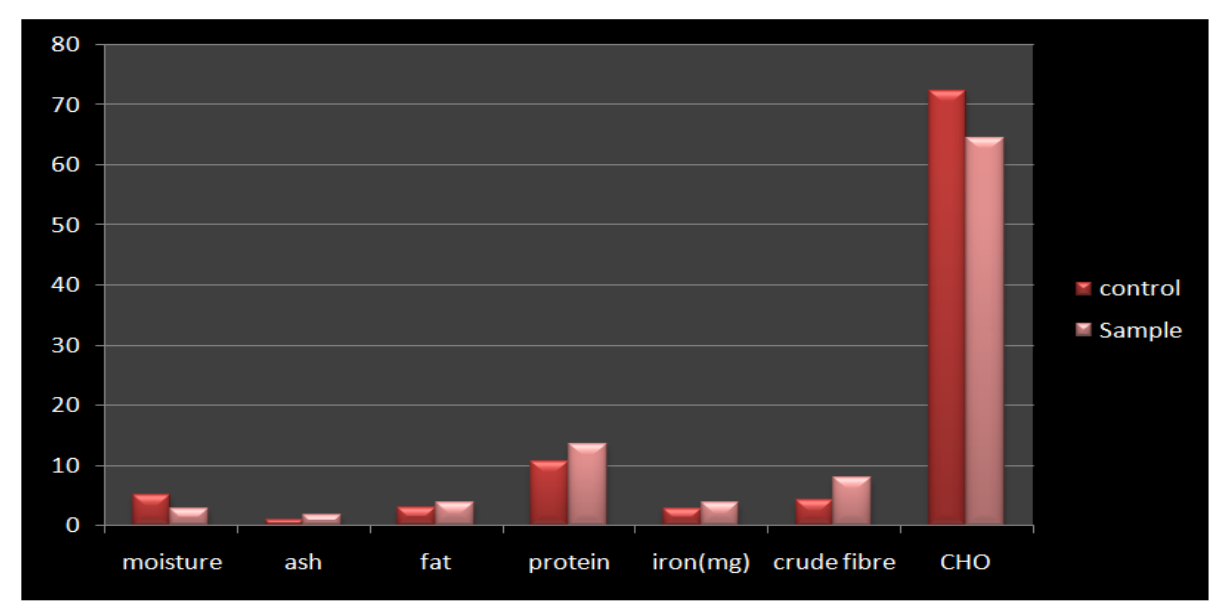

Figure 2 
Table 1

\begin{tabular}{|l|l|l|l|l|l|l|l|}
\hline & Moisture (\%) & Ash (\%) & Fat (\%) & Protein (\%) & Iron(mg) & $\begin{array}{c}\text { Crude } \\
\text { Fibre \% }\end{array}$ & CHO (\%) \\
\hline control & 5.21 & 1.01 & 2.9 & 10.7 & 2.8 & 4.2 & 72.3 \\
\hline Sample & 2.79 & 1.80 & 3.8 & 13.57 & 3.8 & 8.0 & 64.5 \\
\hline
\end{tabular}

Values are means of two observations; Control normal coconut cookies, Sample most acceptable millet flour incorporated coconut cookies.

The carbohydrate content is low in sample when compared to control. This may be attributing to the higher protein content in the most acceptable sample than that of control.

Moisture content was decreased in the sample than that of control due to decrease of moisture up to $5 \%$.A significant increase in the protein content was observed on malting of kodo and little millet and decrease in carbohydrates trough oxidation during germination and loss of low molecular weight nitrogen and rising of grains.

The fat content was increased in sample due to incorporation of butter and coconut. The higher content of fat in butter and coconut could have resulted in higher value of fat obtained in the sample.

There was a significant increase in crude fiber in sample than that of control it may be due to the kodo millet is an excellent source of fiber. The ash content of the sample was increased compared to the control due to the addition of more ingredients like coconut powder etc.

Storage Studies: Table 2 indicates the results for mean scores for different attributes of sensory test and figure 2 shows the analysis of variance for overall acceptability of the stored products. The results for storage studies revealed that both the sample stored in laminated pouch and HDPE was acceptable up to 30 days. After one month the sample stored in laminated pouch got changes in taste and other attributes. The sample stored in HDPE was stable up to 60 days.

Storage studies also revealed that the sample packed in HDPE are more acceptable than that of packed in laminated pouches.

Table 2: Sensory Scores of Cookies

\begin{tabular}{|c|c|c|c|c|c|c|}
\hline Days & Flavour & Taste & Mouth Feel & Colour & Appearance & Overall Acceptability \\
\hline A- & Sample in HDPE pouch \\
\hline 15 & 4.4 & 4.6 & 4.8 & 4.8 & 4.6 & 4.64 \\
\hline 30 & 4.2 & 4.6 & 4.6 & 4.4 & 4.0 & 4.36 \\
\hline 45 & 3.8 & 4.0 & 4.2 & 4.0 & 4.0 & 4.00 \\
\hline 60 & 3.4 & 3.8 & 4.0 & 4.0 & 3.8 & 3.80 \\
\hline B- Sample in laminated pouch \\
\hline 15 & 4.4 & 4.4 & 4.8 & 4.8 & 4.6 & 4.60 \\
\hline 30 & 4.0 & 4.4 & 4.4 & 4.0 & 4.0 & 4.16 \\
\hline 45 & 3.8 & 4.0 & 4.2 & 4.0 & 3.8 & 3.96 \\
\hline 60 & 3.2 & 3.4 & 3.8 & 3.8 & 3.2 & 3.48 \\
\hline
\end{tabular}

HDPE: High density polyethylene 


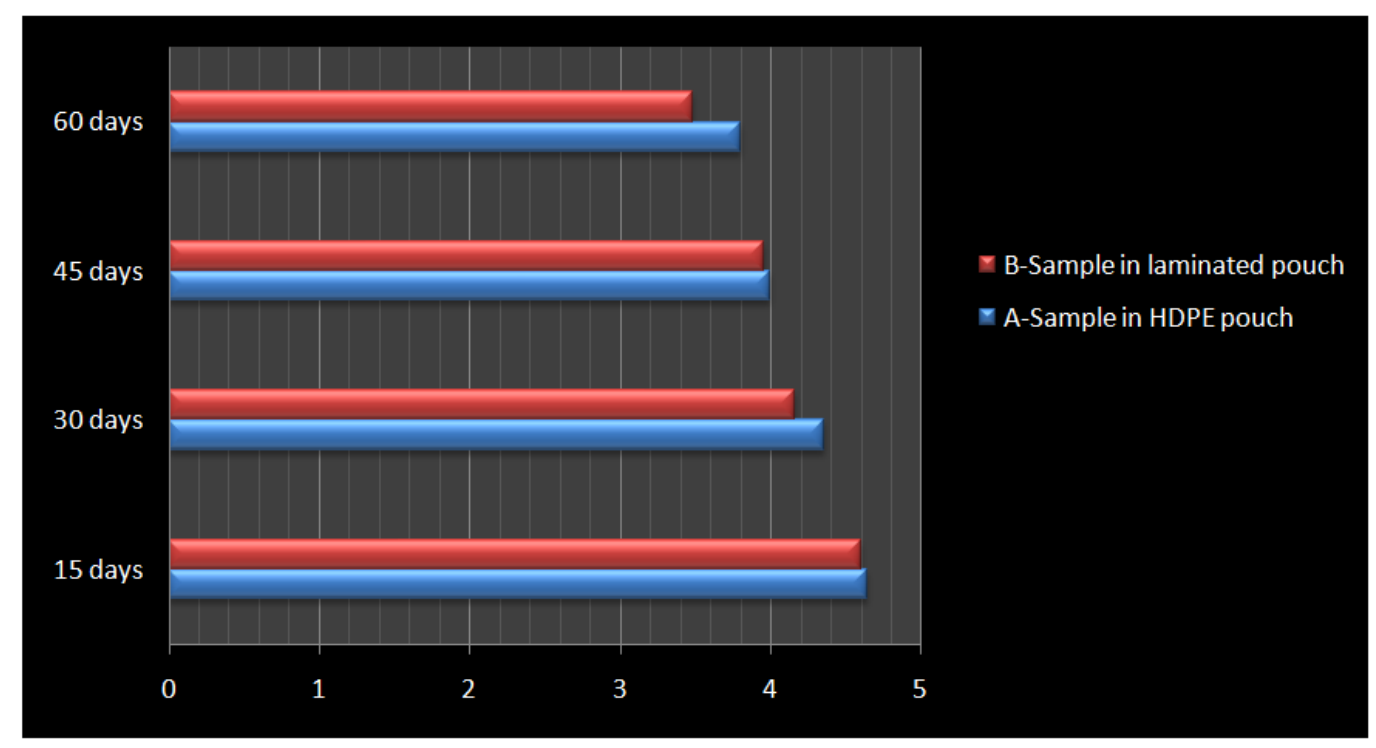

Figure 3: Shelf Life Studies of Sample

\section{CONCLUSIONS}

The present study concludes that millet (kodo \& little) 35:35gms flour incorporated cookies prepared were found to be best combination with respect to sensory evaluation. With increasing health consciousness among people and increasing demand of foods which reduce the risk of diseases, there is tremendous scope and market opportunity for development of such value added products which could find commercial value. These cookies recommended as health foods for all age groups. Because consumption of nutrient dense foods such as those developed will not only help the nutritional status but also provide further health benefits.

\section{REFERENCES}

1. A 'cs, E., Kova' cs, Z., Matuz, J., 1996a. Bread from corn starch for dietetic purposes. I. Structure formation. Cereal Research Communications24, 441-449.

2. A 'cs, E., Kova' cs, Z., Matuz, J., 1996b. Bread from corn starch for dietetic purposes. II. Formation of the visual and technological properties.

3. Cereal Research Communications 24, 451-459.Agu, R.C., Palmer, G.H., 1998.

4. A reassessment of sorghum for lager-beer brewing. Bioresource Technology 66, 253-261.

5. Akingbala, J.O., Rooney, L.W., Palacios, L.G., Sweat, V.E., 1982.

6. Thermal properties of sorghum starches. In: Mertin, J.V. (Ed.),

7. International Symposium on Sorghum Grain Quality. ICRISAT, Patancheru, India, pp. 251-261.

8. Awika, J.M., Rooney, L.W., 2004. Sorghum phytochemicals and potentialimpact on human health. Phytochemistry 65, 11991221.

9. Awika, J.M., McDonough, C.M., Rooney, L.W., 2005. Decorticating sorghum to concentrate healthy phytochemicals. Journal of Agricultural and Food Chemistry 53, 6230-6234.

10. Badi, S.M., Hoseney, R.C., 1976. Use of sorghum and pearl millet floursin cookies. Cereal Chemistry 53, 733-738. 
11. Barredo-Moguel, L.H., Rojas de Gante, C., Serna Saldivar, S.O., 2001a.Comparisons between a commercial wort and a waxy sorghum wortfermented into lager beer, with emphasis on yeast growth and ethanolproduction. Journal of the American Society of Brewing Chemists 59,24-27.

12. Barredo-Moguel, L.H., Rojas de Gante, C., Serna Saldivar, S.O., 2001b.Alpha-amino nitrogen and fusel oils of sorghum worts fermented to lager beer. Journal of the Institute of Brewing 107, 367-372.

13. Belton, P.S., Delgadillo, I., Halford, N.G., Shewry, P.R., 2006. Kafirin structure and functionality. Journal of Cereal Science 44, 272-286.

14. Berti, C., Riso, P., Monti, L.D., Porrini, M., 2004. In vitro starch digestibility and in vivo glucose response of gluten-free foods and their gluten counterparts. European Journal of Nutrition 43,198-204.

15. Beta, T., Corke, H., 2001. Genetic and environmental variation in sorghum starch properties. Journal of Cereal Science 34, 261-268.

16. Beta, T., Rooney, L.W., Waniska, R.D., 1995. Malting characteristics of sorghum cultivars. Cereal Chemistry 72, 533-538.

17. Beta, T., Corke, H., Taylor, J.R.N., 2000a. Starch properties of Barnard Red, a South African red sorghum of significance in traditional African Brewing. Starch/Staerke 52, 467-470.

18. Beta, T., Corke, H., Rooney, L.W., Taylor, J.R.N., 2000b. Starchproperties as affected by sorghum grain chemistry.

19. Journal of the Science of Food and Agriculture 81, 245-251.Beta, T., Rooney, L.W., Marovatsanga, L.T., Taylor, J.R.N., $2000 c$.

20. Effect of chemical treatments on polyphenols and malt quality in sorghum. Journal of Cereal Science 31, 295-302.

21. Brannan, G.L., Setser, C.S., Kemp, K.E., Seib, P.A., Roozeboom, K.,2001. Sensory characteristics of grain sorghum hybrids with potential for use in human food. Cereal Chemistry 78, 693-700.

22. Buffo, R.A., Weller, C.L., Gennadios, A., 1997a. Films from laboratory extractedsorghum kafirin. Cereal Chemistry 74, 473475.

23. Buffo, R.A., Weller, C.L., Parkhurst, A.M., 1997b. Opimization of sulfurdioxide and lactic acid steeping concentrations for wet-milling grain sorghum. Transactions of the American Society of Agricultural Engineers 40, 1643-1648.

24. Buffo, R.A., Weller, C.L., Parkhurst, A.M., 1998. Wet-milling factors of sorghum and relationship to grain quality. Journal of Cereal Science 27, 327-334.

25. .Byaruhanga, Y.B., Erasmus, C., Taylor, J.R.N., 2005. Effect of microwave heating on the functional properties of kafirin films. Cereal Chemistry 82, 565-573.

26. Carr, T.P., Weller, C.L., Schlegel, V.L., Cuppett, S.L., Guderian Jr.,D.M., Johnson, K.R., 2005. Grain sorghum lipid extract reduces cholesterol absorption and plasma non-HDL cholesterol concentration in hamsters. The Journal of Nutrition 135 , 2236-2240.

27. Casier, J.P.J., de Paepe, G., Willems, H., Goffings, G., Noppen, H., 1977.Bread from starchy tropical crops. II. Bread production from pure millet and sorghum flours, using cereal endosperm-cell wall—pentosan as a universal baking factor.

28. In: Dendy, D.A.V. (Ed.), Proceedings of a Symposium on Sorghum and Millets for Human Food. Tropical Products Institute, London, pp. 127-131.

29. Cauvain, S.P., 1998. Other cereals in bread making. In: Cauvain, S.P., Young, L.S. (Eds.),

30. Technology of Breadmaking.Blackie Academic and Professional, London, pp. 330- 346.Choto, C.E., Morad, M.M., Rooney, 
L.W., 1985.

31. The quality of tortillas containing whole sorghum and pearled sorghum alone and blended with yellow maize. Cereal Chemistry 62, 51-55.

32. Chung, O.K., Ohm, J.B., 2000. Cereal lipids. In: Kulp, K., Ponte, Jr., J.G.(Eds.), Handbook of Cereal Science and Technology, second ed.

33. Marcel Dekker, New York, pp. 417-477.Corredor, D.Y., Bean, S.R., Schober, T., Wang, D., 2006. Effect of decorticating sorghum on ethanol production and composition of DDGS. Cereal Chemistry 83, 17-21. 
